\title{
とうもろこしタンパク質ゼインの挙動に与える 有機溶媒の影響
}

\author{
山田浩司 ${ }^{*} \cdot$ 野口明徳 $* *$ 高橋秀和***
}

\section{Effects of the Solvents on Properties of Zein}

\author{
Kohji YAMADA*, Akinori NoGUCHI** and Hidekazu TAKAHASH ${ }^{* * *}$ \\ * University of Tsukuba, 1-1-1, Tennoudai, Tsukuba-shi, Ibaraki 305 \\ **National Food Research Institute, 2-1-2, Kannondai, Tsukuba-shi, Ibaraki 305 \\ *** Showa Sangyo Co., Ltd., 2-20-2, Funabashi-shi, Chiba 273
}

\begin{abstract}
Zein, water insoluble corn prolamin, can be transformed to the transparent, flexible and waterproof film by dissolving into the hydrate organic solvents such as ethyl alcohol and acetone and then drying. However, the resulting film prepared from aqueous ethanol did not show enough waterproof property, compared with the film from aqueous acetone. The behaviour of zein in both solvents and the properties of the resulting films were examined to find possible reasons for their different properties using the following methods ; a particle distribution with laser scattering method, fourier transformation scanning electron microscope, fourier transformation nuclear magnetic resonance, infrared absorption spectroscopy and small angle X-ray scattering (SAXS). SAXS revealed that zein molecule in the film from aqueous acetone had more regular arrangement than that from aqueous ethanol. In addition, zein molecule in aqueous acetone relative quickly formed the basic small aggregates and grew into the huge aggregates, forming the film structure faster than in aqueous ethanol. According to the analysis using FT-NMR, the growing aggregate from acetone was likely to expose their hydrophobic regions outside more than that from ethanol, resulting in the better waterproof property.

(Received Aug. 11, 1995)
\end{abstract}

廃プラスチックによる環境問題および農作物の食品外 用途の開発と連動し，天然物を用いた生分解性プラス チックの開発が世界各国で盛んである，中でもでん物を 用いた素材開発は 1970 年代から始まり， ヨーロッパで は現在, はぼ $100 \%$ でん粉の膨化成型容器が, 食品用発 泡スチロール容器の代替として試用されている. しかし この膨化成型容器は $\alpha$ 化でん粉主体の為, 耐水性が無く その用途は著しく制限されている。こうした問題を解決 する一手段として，とうもろこしの水難溶性タンパク質 ぜンから，生分解性を維持しながら耐水性を示すフィ ルム調製を検討した。 その結果，含水アセトンを溶媒に 用いて耐水性フィルムを調製しうる条件を見出し，含水
エタノールを用いた場合との対比により，破断強度はや や低いが, 優れた耐水性, 透明性, ヒートシール性を有

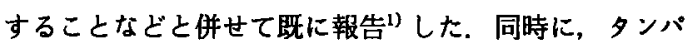
ク質分子溶解時の環境が分子の凝集状態またはフィルム 構造に影響し，これがフィルムの性質に反映されている 可能性を認めた. そこで今回，2 種類の有機溶媒系につ いて，ゼインのフィルム形成に及ぼす影響を検討したの で報告する.

\section{実 験 方 法}

\section{1. ゼイン溶花の調製}

ゼインは, 昭和産業(株)の昭和ッュイン DP と呼ばれ

*筑波大学農学研究科（干300-01 茨城県つくば市天王台 1-1）

** 農林水産省食品総合研究所（干305 茨城県つくば市観音台 2-1-2）

*** 昭和産業株式会社総合研究所（广273 千葉県船橋市日の出 2-20-2） 
る粉末を購入し, SDS-PAGE により夾雑物の存在しな いことを確認してそのまま実験に供した，溶媒としては 水を含んだ 70\% アセトン（v/v）および $80 \%$ エタノー ル（v/v）を用いた. ぜイン $1 \mathrm{~g}$ に対して溶媒 $10 \mathrm{ml}$ を加 元，速や加に擋挥して均一に分散させた後， $50^{\circ} \mathrm{C}$ の水浴 中で 10 分間加熱して完全に溶解させた。調製したゼィ ン溶液は室温で 10 分間冷却した後, 直ちに次の実験に 供した。

\section{2. ゼインフィルムの調製}

ゼイン溶液を， $10 \mathrm{~m} l$ 当たり $130 \mathrm{~cm}^{2}$ の面積になるよ

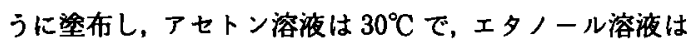

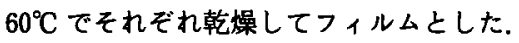

\section{3. 溶液中における挙動の経時的観察}

1) NMR による測定

ゼイン溶液を $40^{\circ} \mathrm{C}$ で静置し，その際の変化を $\mathrm{NMR}$ Analyzer (Bruker 製, NMS-120 型)により, 経時的に 測定した. 測定のための積算回数は 50 回とした.

2）溶液中の微小集合体の測定

ゼイン溶液を自動演算機（Malvern Instruments 製, Multi computing correlater $7032 \mathrm{CN}$ 型）を装備した レーザー散乱型粒度分布測定装置 (Malvern Instruments 製, Zetasizer 3，測定領域：2～5000 nm）を用い て経時的に測定した，尚，ゼイン溶液は，測定直前に $0.45 \mu \mathrm{m}$ のミリポアフィルターで诚過した.

\section{4. 電界放射型走查電子顕微錛による钼察}

観察用試料の調彆は定法に準じて次のように行った。 まずホウ化カリウム結晶の直方体の一面に，その面に垂 直になるように安全剃刀を当てて打ち割り，新しい割断 面を作成した。この割断面上に形成させたぜインフィル ムに，オスミウム酸蒸気による真空プラズマ蒸着処理 ${ }^{2}$ を 0.05 Toor, $1.2 \mathrm{kV}, 10 \mathrm{~mA} ， 20$ 秒の条件にて施した 後, 水中でホウ化カリウム結晶を溶解除去して蒸着試料 片を得た。この試料片を $80 \%$ の含水アルコールで洗浄 してぜインを除去し，オスミウム酸からなるレプリカ膜 を得た。これらの蒸着試料片およびレプリカ膜を電界放 射型走查電子顕微鏡（FT-SEM：トプコン製，DS-720 型）での観察に供した。

\section{NMR によるフィルム中の水分子の観察}

FT - NMR（JEOL 製，JNM - GSX - 270 型, 270.05 $\mathrm{MHz}$ )を用いて, ${ }^{17} \mathrm{O}-\mathrm{NMR}$ 湘定を行うことにより, ぜイ ンフィルムに含まれる水分子の状態を推定した。.フィル ムは水分を $6 \%$ に調整して測定に供し，128 回の積算を 行った.

\section{6. フィルム中のゼイン分子の存在状葾の解析}

1）赤外吸収スペクトルの測定

ポリエチレンシート上で調製したぜインフィルムにつ いて，赤外吸収スペクトルの測定を， MCT 検出器付赤 外分光光度計 (JEOL 製, JIR-6 500 FT-IR) により， 4 $\mathrm{cm}^{-1}$ の分解能で行った，入射角は $45^{\circ}$ とし，接触スぺク トルサンプラーにはセレン化亜鉛を用い, $\mathrm{S} / \mathrm{N}$ 比を充分 取るように 200 回の走查を行った. 近赤外スペクトルの 測定は, TGS 検出器付近赤外分光光度計 (JEOL 製, JRS-6 500 FT-Raman）を用い，200 回の積分から求め た.

\section{2） 円偏光二色性の湘定}

フィルムの円偏光二色性 (CD) を Spectropolarimeter（日本分光(株)製，J-720）を用いて，波長は 250 $\sim 350 \mathrm{~nm}$ ，積算数は 100 回にて测定した.

\section{実験結果及ひ考察}

\section{1. ゼイン溶液の観察}

ゼインフィルムは原料の粉末と同様の可溶性を示し, その溶液からフィルムが綝り返し調製できる。 また，こ れらのフィルムは使用する溶媒の種類に応じて異なる耐 水性を示す．したがって，ゼインフィルムの耐水性発現 は，タンパク質の不可逆的な変性に依るものでないと考 えられる．このゼインは古くからプロラミンに分類され る疎水性タンパク質として報告されてきたが，分子内の 眯水性了ミ/酸含量は約 65 モル\% であり，4割近くは 親水性アミノ酸である。.さてタンパク質の構造について は，中間的構造の存在㩐力学的な計算により導加れて おり，二次元 NMR を用いた球状タンパク質に関する最 近の研究では，モルテングロビュール゙3) と呼ばれる中間 的な構造状態について, 平衡論的あるいは速度論的に明 らかにされっつある。これらの情報を基にして我々は， 種々の溶媒から調製したフィルムの耐水性差異を理解す るために，ゼイン分子同志の集合状態が溶媒の極性に応 じて異なり，それが溶媒蒸散時のゼイン分子配列に影䈉 して, フィルム形成後の耐水性の有無に反映されるとい うモデルを提唱した ${ }^{1)}$ ．蹯水性蛋白質の中でもフィブロ インやケラチンは, 構造状態のいくつかがかなり明確に されている.しかしぜインういては，ARGOSを始め 2 , 3 の報告(4) ${ }^{45}$ が認められる程度であり，しかも意見の一 致に至っていない。

ここでは先ず，アセトンとェタノールの両溶媒中にお いてゼイン分子の挙動を各種手法を用いて比較検討する 事により, 溶液中での分子状態と溶媒との関係をより明 確に把握しよう之試みた。溶液中のタンパク質の立体構 
造を考察するには，各種の分光光学的手法が簡便且つ多 様な測定法として知られている゙）。かしながら含水ア セトンのUV透過率は極端に低く，80\%の透過率を示 す波長でさえ $340 \mathrm{~nm}$ 付近であり，より短波長では UV に対し完全に不透明となる，従って，吸収スペクトルを はじめ, 円偏光二色性，旋光分散等の测定は不可能で あった. また, タンパク質分子中の疎水領域が，水溶液 中でどの程度分子表面に配位しているかを見積もるに は，疎水性蛍光プローブでタンパク質をラベルする手法 が一般に用いられる.しかし，本実験で用いた溶媒系に 試みたところ，アセトン及びェタノールのどちらの系に おいても, 溶媒自体に起因する蛍光強度が非常に強く, 溶液中のゼインについて観察することは不可能であっ た. ゼイン溶液の分析に用いた NMRは，系全体をバル クとして測定するもので, 情報は通常, 系に含まれる固 体成分の量として\%値で表される：SFC（Solid Fat
Content). 2 つの系において蛋白質分子の集合状態が異 なる場合，例えばタンパク質表面の親水領域分布が異な る場合には，SFCに反映されるものと考えた. それぞれ 溶媒のみの系を対照区としぜインを溶解させた場合につ いて測定を行ったが, S/N 比が小さく両者の比較は為し 得なかった。

以上のように, 溶液中の分子構造について直接に比較 を行うことは非常に困難であったが，レーザー散乱測定 装置による観察では，顕著な相違が認められた（Fig. 1). 溶解直後のエタノール中では, 見かけ直径 20〜35 $\mathrm{nm}$ 及び 150〜 450nm と湘定される二種類の分布状態が 観察された.これに対しアセトン系では，17〜19 $\mathrm{nm}$ のみ存在を認めた.ささて, 含水エタノール中のぜイン分 子は長円形むしくは棈円体でそのサイスは 10〜20×0.4 $\sim 1.5 \mathrm{~nm}^{7)}$ と報告されている. 本研究にもこの数值を適 用すると, 測定可能領域内 $(2 \sim 5000 \mathrm{~nm})$ では溶解直後
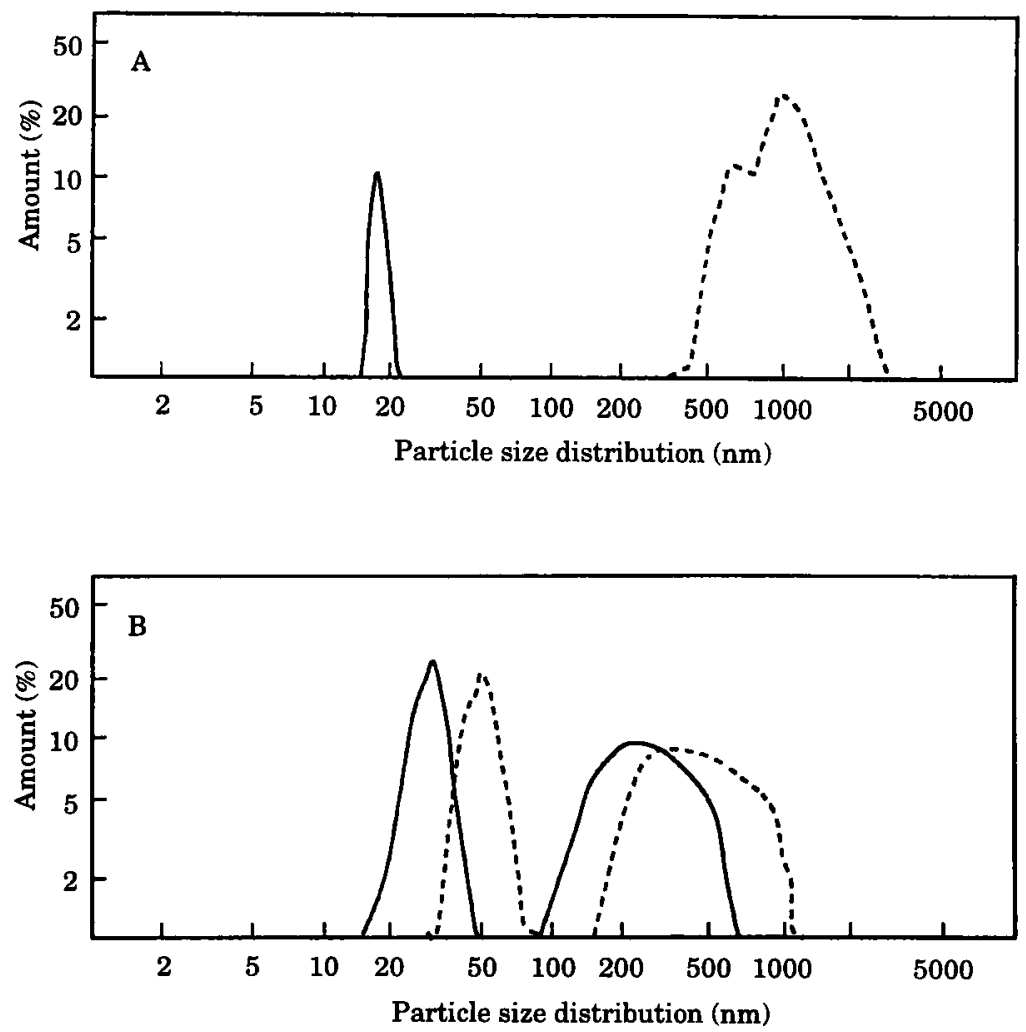

Fig. 1 Particle size distribution of zein in solvents

$A$, acetonic solution ; $B$, ethanolic solution.

$\longrightarrow, 0 \mathrm{~min}$ after dissolving at $45^{\circ} \mathrm{C}$;

$\cdots \cdots$, leaving at $45^{\circ} \mathrm{C}$ for $20 \mathrm{~min}$ after dissolving. 
に, エタノール系では 2〜4 分子および $(1 \sim 27) \times 10^{3}$ 分 子程度の 2 グループの集合体を形成し，アセトン系では ほぼ笚分子に近い状態で存在していると考えられる. 集 合状態の経時変化においても，溶媒間で明らかな差異が 観察された. 即ち、エタノール系では，比較的小型の集 合状態と大型の集合状態の 2 種類が常に存在した.これ らは時間と共に徐々に成長し，80 分以降では 5〜10 nm および 280〜 430 nm を主成分とする 2 グループが安定 に存在する様子が認められた，一方アセトン系では，比 較的大型の集合状態が単独で観察されるのみであった. その成長速度および最終的な大きさはエタノール系に比 ベ, 極めて大きいことが認められた.これは, エタノー ル系中のゼイン分子がその環境下で安定な溶解状態を維 持しているのに対して，アセトン系に一旦溶解されたぜ イン分子は，それ自体の自由度がェタノール系に比べて 高く, 分子間の相互作用がより発現できるためと考えら れる. したがってフィルム形成時には，分子相互の結び つきがェタノール系に比べて強固なため, 可撓性がやゃ 劣るフィルムが形成されることになると予想されるが, これは先に報告”した実際のフィルムの物性と一致す る.

\section{2. ゼインフィルムの観察}

フィルムの FT-SEM による観察画像を Fig. 2 に示し た. エタノール系においては, フィルム全域にわたって, ほぼ完全な球形をした粒子状構造が多数観察され，その 下部にフィルムとしての構造が観察された．粒子状構造 の疑似直径は $0.2 \sim 2 \mu \mathrm{m}$ の範囲であった．これは溶液内 で形成された集合体が，溶媒の蒸発過程で，さらに成長 しつつ同時に相互に接着しながら固定されたものと考え られる. 他方, アセトン采のフィルム表面は全域で平滑 かつ均質であった，粒子状構造はその表面に, 融着した 状態で散在する様子が認められた. 個々の粒子形状はエ タノール系と同嵄にほぼ完全な球形だが，その直径は $0.2 \mu \mathrm{m}$ 内外之 $1 \mu \mathrm{m}$ 内外の 2 グループに大別された。 ま た,アセトン溶液のレーザー散乱に於いて観察された比 較的大型の集合体は,フィルム中には観察されなかっ た.これは，ェタノール系に比べて，より大きな集合状 態を速やかに形成するため，最終的に粒状構造としては 観察され得なかったものと思われる.

X 線小角散乱（SAXS）による予備的分析を行ったと ころ, アセトン系フィルム中においてのみ，分子の配列 にある種の規則性を認めた. 一方, 赤外吸収スペクトル の湘定結果からは，アセトン系とエタノール系との間に 差異は見いだせず，フィルムを構成しているゼイン分子
自体の二次構造には，殆ど差異が無いものと考えられ た.タンパク質の構造解析における CD スペクトルは,

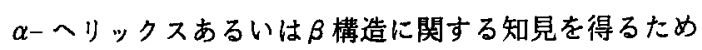
に紫外部よりの領域について測定することが多いが，本 研究では赤外吸収スペクトルの結果に基づき, 比較的長 波長側の湘定のみを試みた。 その結果, 両フィルムとも に 255〜280 nm に複数の CD 帯を認めたが, そのスペク トルパターンは明らかに異なっていた（Fig. 3). 旋光性 は, アルコール系フィルムでは正, アセトン系フィルム では負と, 逆の性質を示し, 且つモル楕円率 $[\theta]$ はアセ トン系の方が大きな値を示した。この吸収帯はチロシ ン, フェニルアラニン等の芳香族アミノ酸側鎖に基づく とされている. 一方, へムペプチドに関する研究では, 単量体の示すガウス曲線様の単純な CD スペクトルが, 会合状態になるとCD 帯数の増加, 負の CD 帯の出現等 の変化を生じること, およびこれらの変化の様子は会合 状態に応じて異なることが報告8) されている，したがっ て，2 種類のゼインフィルムのスペクトルパターンにお ける差異は, 䟱水性ア ミ，酸側鎖の存在状態あるいは構 造状態が両フィルムで異なることならびに，ゼイン分子 の会合状態が両フィルムで異なることを示唆していると 考えられる。

両フィルムについて得られた FT-NMR スペクトルを Fig. 4 に示した。一般にシグナルの線幅は水分子の自由 度の増加に連れて減少するが, 本実験では両試料の測定 条件が同一なのでそのまま ppm 表示により比較しだ9. その結果,エタノール溶液から調製したフィルムでは, アセトンの場合の約 70\%の值となった.これはェタ ノール系フィルム中での自由度が高く，逆にアセトン系 フィルム中で水分子がより強く拘束されていることを示 すあのである. 水分子が拘束されているのはタンパク質 の疎水領域と予測されることから，エタノール系フィル ムを構成している基本構造体としては，その表面に親水 性の側鎖がより多く罢出しており，それに対してアセト ン系フィルムでは疎水性侧銷がより多く露出していると 考えられる (Fig. 5). この結果に基づき，耐水性の発現 機作について次のように結論づけた. 水と接触した場 合, アルコール系フィルムは個々の基本構造体がその親 水領域を介して水を受け入れるため速やかに膨溜崩壊 し，耐水性を発現し得ない，一方，アセトン系フィルム では，相互の分子あるいは基本構造体は蹯水結合により 強固に結合されており，水分子はその間には侵入し得な いため極めて縓慢な拡散が生じるのみとなり，水と接触 しても崩壊することなく優れた耐水性を示す。 
A

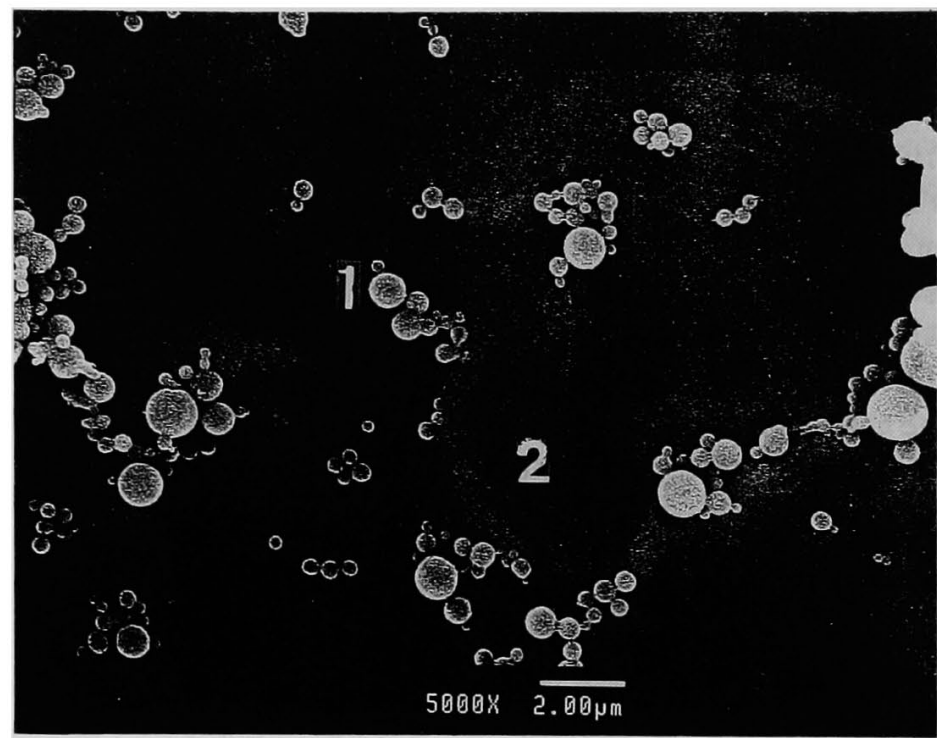

$\mathrm{B}$

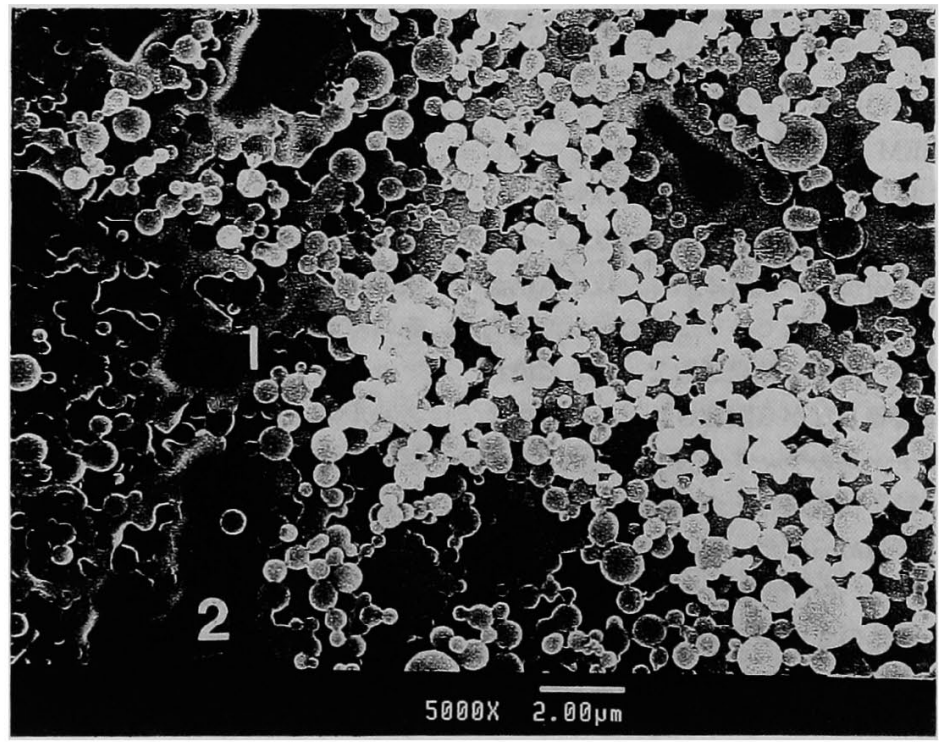

Fig. 2 Fine structure of zein films prepared from acetonic and ethanolic solutions A, the film from acetonic solution ;

A few globules (1) were observed on the film (2) which showed the vague pattern of tortoiseshell.

B, the film from ethanolic solution; Many small globules (1) were observed on the surface of film (2) which was unclear in this figure.

The white bars in the figure correspond to $2 \mu \mathrm{m}$. 


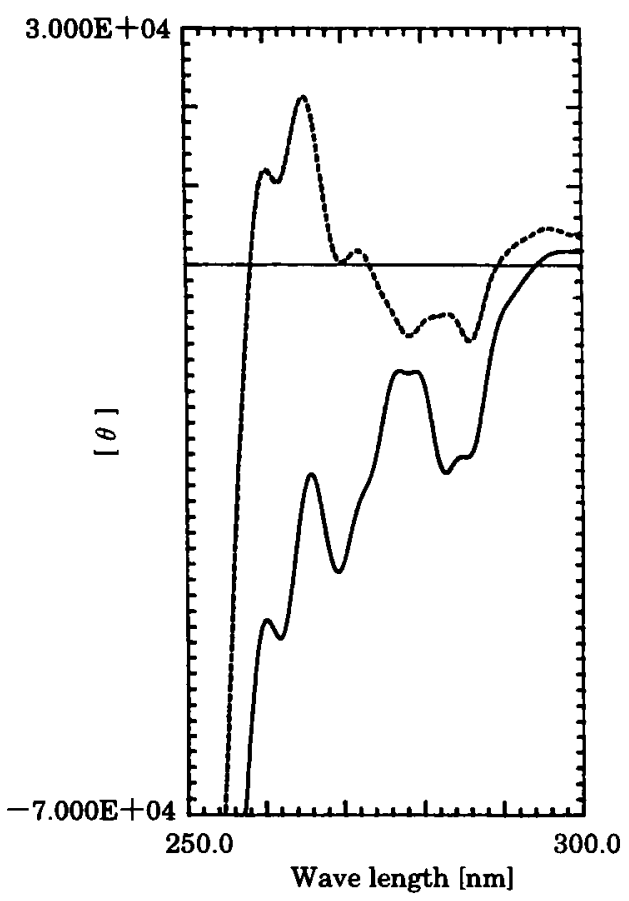

Fig. 3 Circular dichroism of zein films

- film made from acetonic solution ; ...... film made from ethanolic solution.

$[\theta]$, molar ellipticity $\left(\mathrm{deg} \cdot \mathrm{cm}^{2} \cdot \mathrm{dmol}^{-1}\right)$.

\section{要 約}

ゼインの溶液およびフィルムについて，アルコール系 とアセトン系との比較を，レーザー散乱型粒度分布湘定 装置, FT-SEM, FT-NMR, 赤外吸収スペクトル, CD, SAXS を用いて行った. その結果，ゼインフィルムの耐 水性の有無については次のモデルを提唱できると考え る. アセトン系とエタノール系ではゼイン分子の集合状 態が明らかに異なり，アセトン溶液中では，分子表面に 㾊水性了ミ/酸がより多く分布していたために分子間の 相互作用が強い，そのため一旦分子同志が集合し始める と,その速度および結合力はエタノール系に比べて大き く，集合体の椆密度も高い．この凝集過程において構築 される構造体がフィルム形成の最小単位と考えられ，し たがって, アセトン系フィルムは水と接した場合, 水と の作用に抗して構造を維持する力が大きく，且つ水と馴 染み易い領域の少ない構造状態となる，そのため，可撓 性はやや低い值をとるが，水に対する抵抗性は大きな值 を示すようになる.
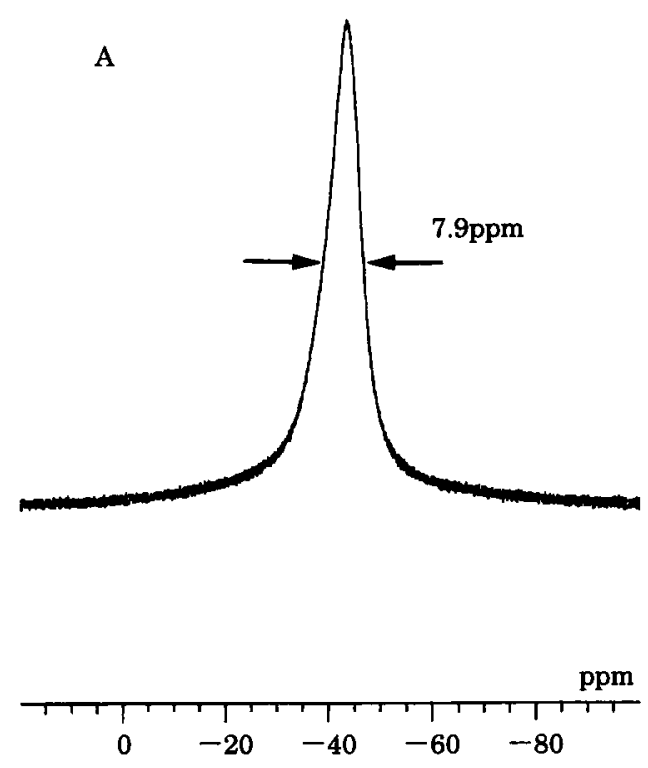

B

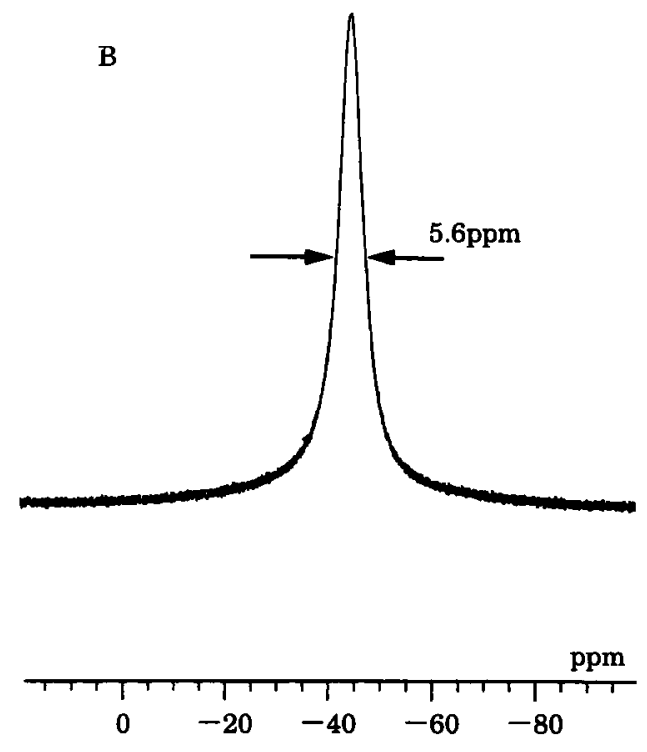

Fig. 4 FT-NMR spectra of zein films

A, film made from acetonic solution ; B, film made from ethanolic solution.

本研究を行うに当たり, 赤外吸収スぺクトルおよび X 線小角散乱の測定についてはそれぞれ関西学院大学・理 学部・化学科・尾崎幸洋教授, ヨーロッパ放射光研究 所・若槻荘市博士のご協力を睗りました，FT-SEM は 


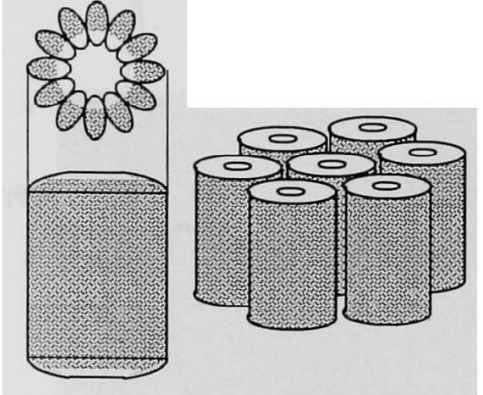

A
B

Acetone

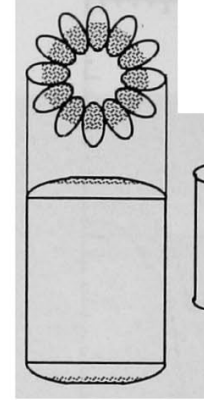

A

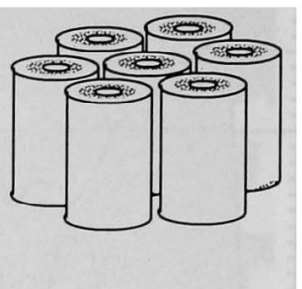

B

Ethanol

Fig. 5 Possible mechanism of film formation from zein solution

Acetone A, basic aggregates exposing the hydrophobic region of zein molecules; B, transformation to the film from the basic aggregates through the hydrophobic interaction.

Ethanol A, basic aggregates exposing the hydrophilic region of zein molecules; $\mathrm{B}$, transformation to the film from the basic aggregates through the hydrophobic interaction.

Gray zone shows hydrophobic region.

物質工学研究所 - 構造解析研究室 ·八瀬清志室長に, ま た溶液の NMR 分析では機能水研究所(株) - 荒田洋治所 長にご協力いただきました，此処に感謝の意を表しま す.

\section{文献}

1) Yamada, K. and Noguchi, A.: 84th Am. Oil Chem. Soc. Annual Meeting Abstracts, 524, California (1993).

2) ТАNAKA, A.J. Electron Microsc., 43, 177 (1994).

3) DeGrado, W.F.: Nature, 365, 488 (1993).

4) Argos, P., Pederson, K., Marks, M.D. and LARKINS, B.A. : J. Biol. Chem., 257, 9984 (1982).

5) Garratt, R., Oliva, G., Caracelli, A. and
ARRUdA, P. : Proteins Struct. Funct. Genet., 15, 88 (1993)

6）タンパク質化学, 3 巻, 安藤鋭郎・今堀和友 · 伊 勢村寿三・早石 修編 (共立出版, 東京), p. 344 (1973).

7) Tatham, A.S.. Field, J.M., MorRis, V.J., I' Anson, K.J., Cardle, L., Dufton, M.J. and Shewry, P.R. : J. Biol. Chem., 268, 26253 (1993).

8）浜口浩三・武貞啓子 : 生物化学実験法, C.4 巻, 瓜谷郁三・志村憲助・中村道徳・船津 勝編（東 京大学出版会, 東京), p. 185 (1971).

9）玉城 武・松下和弘・桶岡克哉 高宮義治 : 農 化, 60, 191 (1986).

（平成 7 年 8 月 11 日受理） 